Int. J. Electrochem. Sci., 15 (2020) $8181-8189$

International Journal of

ELECTROCHEMICAL

SCIENCE

WWW.electrochemsci.org

\title{
A Facile synthesis of the Nickel Oxide Nanoparticles for the Effective Electrochemical Detection of Hydrogen peroxide in Contact Lens Solution
}

\author{
Praveen Kumar $G^{l}$,Selvarasu Maheshwaran ${ }^{l}$, Shen-Ming Chen ${ }^{1, *}$, Muthumariappan Akilarasan ${ }^{1}$, \\ Tse-Wei Chen ${ }^{2,3,4}$, Tien-Wen Tseng, ${ }^{2, *}$ Jaysan $\mathrm{Yu}^{4}$, Richard $\mathrm{Yu}^{4}$, \\ ${ }^{1}$ Electroanalysis and Bioelectrochemistry Lab, Department of Chemical Engineering and \\ Biotechnology, National Taipei University of Technology, Taipei, Taiwan 106 (ROC). \\ ${ }^{2}$ Department of Chemical Engineering and Biotechnology, National Taipei University of Technology, \\ Taipei 10608, Taiwan, ROC \\ ${ }^{3}$ Research and Development Center for Smart Textile Technology, National Taipei University of \\ Technology, Taipei 106, Taiwan, ROC. \\ ${ }^{4}$ Well Fore special wire corporation, 10, Tzu-Chiang 7 rd., Chung-Li Industrial Park, Taoyuan, Taiwan \\ *E-mail: smchen78@ms15.hinet.net, f10403@ntut.edu.tw
}

doi: $10.20964 / 2020.08 .69$

Received: 6 May 2020 / Accepted: 10 June 2020 / Published: 10 July 2020

Hydrogen peroxide $\left(\mathrm{H}_{2} \mathrm{O}_{2}\right)$ was secreted in the mitochondria during the cell production. Moreover, $\mathrm{H}_{2} \mathrm{O}_{2}$ was act as a key member for reactive oxidative species. The imbalance of reactive oxidative species causes various health risks. Therefore, it is important to develop a device to detect $\mathrm{H}_{2} \mathrm{O}_{2}$. Thus, nickel oxide nanoparticles ( $\mathrm{NiO} \mathrm{NPs}$ ) were synthesized using the simple co-precipitation method for the detection of $\mathrm{H}_{2} \mathrm{O}_{2}$. The morphological and chemical composition of the as prepared $\mathrm{NiO} \mathrm{NPs}$ was characterized by using FESEM and XRD. Herein, we reported that the synthesized NiO NPs modified GCE shows a selective detection towards the $\mathrm{H}_{2} \mathrm{O}_{2}$. Moreover, the NiO NPs/GCE has displayed wider covering range of $8.6 \mathrm{nM}$ to $433.24 \mu \mathrm{M}$ with the detection limit up to $4.28 \mathrm{nM}$. The NiO NPs/GCE has successfully examined with contact lens cleaning solution for the practical application for detection of $\mathrm{H}_{2} \mathrm{O}_{2}$, which shows the appreciable found and recovery.

Keyword: Nickel oxide; $\mathrm{H}_{2} \mathrm{O}_{2}$ sensor; reactive oxidative species; electrochemical method; contact lens cleaning solution.

\section{FULL TEXT}

(C) 2020 The Authors. Published by ESG (www.electrochemsci.org). This article is an open access article distributed under the terms and conditions of the Creative Commons Attribution license (http://creativecommons.org/licenses/by/4.0/). 
